\title{
O PROBLEMA DO RISO EM $O$ NOME DA ROSA, DE UMBERTO ECO
}

\author{
The laugh trouble in The name of the rose, \\ by Umberto Eco
}

\author{
Paulo de Góes
}

Doutor em Filosofia pela Unicamp e professor titular da Universidade de Sorocaba. Sorocaba, SP - Brasil,e-mail: lipa@splicenet.com.br

\begin{abstract}
Resumo
Umberto Eco, em seu conhecido romance $O$ nome da Rosa, explora a questão referente ao riso, reproduzindo uma velha discussão histórica e filosófica que se reporta ao segundo livro da Poética, de Aristóteles, considerado perdido, no qual o filósofo, ao tratar da comédia, faz uma apologia do riso e suas virtudes. Duas tendências são confrontadas: uma, que tem como representante o velho monge e bibliotecário Jorge de Burgos, que define o riso como fonte de dúvida e defende que ele não deve ser livremente permitido como meio para afrontar a adversidade do dia-a-dia, e outra, representada por Guilherme de Baskerville, fundamentada em Aristóteles e seus comentadores que consideravam o riso como "próprio do homem", sinal da racionalidade humana. Este artigo tem como objetivo explorar a duas tendências, percorrendo, de modo ligeiro, as páginas do romance, inserindo digressões de ordem histórica e filosófica.
\end{abstract}

Palavras-chave: Idade Média. Riso. Comédia. Vida monástica. 


\begin{abstract}
Umberto Eco, in his outsdanding novel The Name of the Rose, explores the question referring to laughing, reproducing an old historical and philosophical discussion that reports to the second book of Aristotle's Poetics, considered lost, in which the philosopher, concerning to comedy, makes an apology of laughing and its virtues.Two tendencies are faced: the first, represented by the old librarian and monk Jorge de Burgos, who defines laughing as a source of doubt and defends that it can't be freely allowed as a way to face daily adversity; the second, represented by Guilherme de Baskerville, based in Aristotle and his commentators that considered laughing as "pertaining to man", signal of human rationality. This article proposes to explore the two tendencies, running lightly through the pages of the novel, inserting digressions of historical and philosophical orders.
\end{abstract}

Keywords: Middle-Ages. Laughing. Comedy. Monastic life.

Umberto Eco, em seu conhecido romance $O$ nome da Rosa ${ }^{l}$, que alcançou notável êxito editorial, explora uma questão interessante sobre o riso ${ }^{2}$ que reproduz uma velha discussão histórica e filosófica. A questão gira em torno do segundo livro da Poética, de Aristóteles, no qual o filósofo, ao tratar da

1 O título do livro surgiu da frase com que encerra a obra: "Stat rosa pristina nomine, nomina nuda tenemus”. A expressão pode ser assim traduzida: “A rosa antiga permanece no nome, nada temos além do nome”. A frase lembra uma figura retórica da poesia medieval e teria surgido não de modo planejado conforme confessa Eco. O título da obra não havia sido definido anteriormente. Tinha na cabeça vários outros e essa frase, bem como o título, surgiram num último momento, ao terminar a redação (ECO, 1985, p. 7-10), ainda a entrevista de Eco ao jornal mexicano La Jornada Semanal, México, 2 e 9 de enero de 2002. Acrescentamos que ao se ver na "rosa” uma referência ao verso de Shakespeare (“a rose by any other name”) há um equívoco. A citação significa que as coisas deixam de existir e ficam somente as palavras, enquanto que o autor inglês diz exatamente o oposto: as palavras não servem para nada; a rosa seria rosa com qualquer outro nome.

2 Isso é demonstração de que as convenções inerentes ao riso ganharam diferentes conotações no tempo e no espaço, mesmo em grupo sociais diferentes de uma mesma comunidade. Porém, o riso, fenômeno universal, não obstante as variações, tem seu lugar sempre determinante na economia dos gestos e dos atos sociais. (DUVIGNAUD, 1985, p. 20-22). 
comédia, faz uma apologia do riso e suas virtudes. Apesar de esse livro ser considerado perdido, ${ }^{3}$ isso não impede que os estudiosos monges discutam sobre o tema naquela abadia onde a trama de Eco se desenvolve.

Nesse sentido, o leitor, mesmo aquele leitor considerado especialista sente-se envolvido pela erudição de Eco que, ao abordar o assunto, em diversas ocasiões, expõe as opiniões antigas e medievais sobre o riso, registrando ditos de Sinésio de Cirene, Élio Esparciano, Ausônio, Paulino de Nola, Clemente de Alexandria, Sulpício Severo, Efrém, o siro, João Crisóstomo, João de Salisbury, etc. Retrata que, no Ocidente medieval, não havia uma opinião unificada sobre o riso. Os testemunhos acessíveis mostram uma variedade de atitudes, oferecendo, portanto, um quadro atraente no contexto da história cultural. É sabido que Efrém ${ }^{4}$,

3 De fato, há indícios que levam a crer que, da Poética, perdeu-se o segundo livro, voltado para a discussão da comédia. No início do capítulo VI (1449b 21-22) há uma forma promissiva que adia uma discussão: “trataremos mais tarde”. Refere-se à poesia épica e à comédia, pois, a seguir, passa a tratar da tragédia. Contudo, no texto que possuímos, apenas parte desse compromisso é efetivamente cumprido, visto que, a partir do cap. XXIII, volta a atenção para a epopeia. Porém, o tratamento dispensado à poesia épica é muito menos amplo e detalhado que o dispensado à tragédia. Além disso, o códice Parisinus 1741 (séc. X-XI), que contribuiu para o estabelecimento do texto da Poética, traz palavras finais corrompidas, de difícil leitura, interpretadas geralmente como: "a respeito dos iambos e da comédia, por sua vez, escreverei”. Testemunhos externos devem ser lembrados. Diógenes Laércio, no seu catálogo das obras de Aristóteles, arrola Tratado da Arte Poética, em dois livros. Esse tratado é a Pragmateia, uma espécie de apostila bem-acabada sob ponto de vista da redação, para uso dos alunos do Liceu, e que se perdeu, restando a obra que conhecemos hoje sob o título de Poética, um apanhado de notas de aula para uso exclusivo do filósofo. Eustrácio (c. 110 d. C.), no comentário à Ética a Nicômaco, refere-se "ao primeiro livro de Aristóteles sobre a poética” e a Vita Hesychiana menciona um segundo livro da Poética. Lembre-se ainda que o explicit da tradução latina de Guilherme de Moerbeke diz respeito ao primus Aristotelis de arte poetica líber. (KASSEL, 1965, p. 40; YEBRA, 1974, p. 14, nota 13).

4 (apud CURTIUS, 1957, p. 441). Estamos nos servindo da primeira edição desta obra clássica que, no cap. IV do Excurso ("Gracejo e seriedade na literatura medieval”) procura mostrar opiniões diferenciadas sobre o riso na Idade Média e na Antiguidade Tardia. A Editora da Universidade de São Paulo e a Hucitec relançaram a obra em 1994, que leva, no original o seguinte título: Europäische Literatur und lateinisches Mittelalter. Foi utilizada a mesma tradução de Teodoro Cabral e Paulo Rónai, tendo como base a primeira edição alemã. Porém, foram introduzidos acréscimos de autoria de Geraldo Gerson de Souza, com base na segunda edição alemã, considerada a definitiva. Traz, também, uma introdução que vale por um ensaio, sob o título de Curtius, de autoria de Segismundo Spina. Modesto Carone, em resenha publicada na Folha de S. Paulo, em 27 de novembro de 1994, embora afirme que a reedição é um empreendimento de envergadura e uma prestação de serviço ao leitor brasileiro, faz algumas observações sobre a tradução com base apenas no Prefácio e, depois, suposições em relação ao texto integral. Mas não deixa de considerar um dos lançamentos mais substantivos daquele ano. Infelizmente, ambas as edições em nossa língua estão esgotadas. 
falecido por volta de 373 d. C., declarado doutor da Igreja desde 1920, compôs uma parênese contra o riso dos monges e que, por outro lado, na tradição aristotélica, o riso era considerado pertencente à essência do homem.

Eco, com notável propriedade, procura mostrar que a fronteira entre o cômico e o sério não está bem delimitada na Idade Média. Ainda que a Igreja discuta a licitude do riso, nos tempos medievais, há uma propensão para se misturar os opostos. Daí a existência de motivos cômicos nos relatos hagiográficos, inclusive nos relatos dos martírios, como se verá adiante. Por outro lado, há atitudes que medeiam os dois extremos. Sulpício Severo, por exemplo, afirma de S. Martinho: “[...] nemo umquam illum vidit iratum, nemo commotum, nemo maerentem, nemo ridentem” (Jamais alguém o viu irado, nem comovido, nem triste, nem risonho) (CURSIUS, 1957, p. 441).

Todo esse inventário é coerente com a forma de se pensar ao longo do medievo, visto que havia um profundo respeito para com as auctoritates $^{5}$ e, quando defensores de posições antagônicas se esgrimiam através dos argumentos, a obra dos predecessores formava um argumento comum. Não é surpreendente, portanto, encontrar-se, às vezes, uma espécie "collage", um aluvião de argumentos alheios, misturando, inclusive, o sério ao risível. Isso ratifica a velha frase, repetida pelo franciscano Baskerville ("somos anões em ombros de gigantes”), em consonância com a escola de Chartres. ${ }^{6}$

Na obra, especialmente as duas tendências são confrontadas. Uma é a que tem como representante o velho monge e bibliotecário Jorge de Burgos, ${ }^{7}$ que define o riso como fonte de dúvida e defende que o mesmo não deve ser livremente permitido como meio para afrontar a adversidade do dia-a-dia, visto que pode ser usado como arma para desacreditar a própria Igreja. Essa tendência é seguida pelos monges que integravam a abadia onde as cenas do romance se desenvolvem. A justificativa teológica (mas não lógica) é a de que o riso mata o temor e isso, por sua vez, impede a fé. Outra é a abordagem fundamentada

5 Consideradas fontes do conhecimento que serviam de referência aos pensadores medievais, pois só podiam rubricar com o peso de algumas delas.

6 (ECO, 1989, p. 94, 103). Segundo João de Salisbury, no Metalogicus III, 4, esta frase é devida a Bernardo de Chartres, mas foi utilizada por muitos autores.

7 Este personagem assemelha-se a Bernardo de Claraval, que se opôs à representação de figuras monstruosas na arte românica. Por outro lado, Eco confessa: “Todos me perguntam por que o meu Jorge, pelo nome, evoca Borges, e por que Borges é tão perverso. Mas eu não sei. Eu queria um cego como guardião de uma biblioteca... e biblioteca mais cego só pode dar Borges... Mas quando coloquei Jorge na biblioteca, ainda não sabia que ele era o assassino. Ele fez tudo sozinho, por assim dizer.”(ECO, 1985, p. 26). 
em Aristóteles e seus comentadores, que teve, ao longo da história, desdobramentos diversos. Essa tendência é representada, no romance, por Guilherme de Baskerville, ${ }^{8}$ o arguto franciscano que encara o riso como pertencente à essência do homem, sinal da racionalidade do humano e instrumento para se lidar com as vicissitudes da vida.

Este artigo tem como objetivo explorar tais tendências, percorrendo, de modo ligeiro, as páginas do romance, e fazendo pequenas digressões de ordem histórica e filosófica para situar os fundamentos da velha discussão. Obviamente, por questão de espaço não são citadas e comentadas todas as passagens referentes ao assunto. Deteve-se naquelas que foram julgadas as mais relevantes.

Para análise das duas correntes acerca do riso que se mostram no romance de Eco, partiremos exatamente de uma cena que tem lugar no scriptorium, próximo à biblioteca. Ao tomarem conhecimento das ilustrações de Adelmo de Otranto (primeira vitima de uma sucessão de mortes misteriosas que acontecem no mosteiro), os monges começam a rir. Então, aparece a figura estranha de Jorge de Burgos que, de modo severo, repreende: "Verba vana aut risui apta non loqui” (Não falar palavras frívolas ou aptas a excitar o riso). ${ }^{9}$ Mas de que riam eles? As imagens retratavam uma região aonde se chega cavalgando um ganso azul. Ali existiam gaviões que pescavam num regato e ursos que perseguiam falcões no céu, além de camarões que voavam com as pombas e gigantes presos numa armadilha, bicados por um galo.

Jorge de Burgos justifica sua observação: “Ouvi pessoas que riam de coisas risíveis e lembrei-lhes um dos princípios de nossa regra. E como disse o salmista, se o monge deve abster-se de boas conversas pelo voto de silêncio, por muito maior razão deve subtrair-se às más conversas" (ECO, 1989, p. 87). Referia-se à conversa sobre as imagens do ilustrador (“más imagens”) que estariam mentindo acerca da forma da criação, mostrando o mundo ao contrário daquilo que deveria ser.

Guilherme de Baskerville, ao contrário, considerava que as imagens marginais do ilustrador induziam ao riso, não para a subversão, mas para a edificação. As ilustrações são justificadas pelo franciscano desta maneira: "Como nos sermões, para tocar a imaginação das multidões piedosas, ocorre inserir-se exempla, não de raro jocosos, assim também, o discurso

8 Representante da faceta racionalista, sempre buscando as causas para explicar os efeitos, talvez por influência de Tomás de Aquino a quem o autor jamais negou sua grande admiração.

9 (ECO, 1989, p. 86). Trata-se da reprodução do cap. IV da Regra de São Bento. Seria bom registrar a frase seguinte do mesmo capítulo: "risum multum aut excussum non amare” (não amar o riso demorado ou forte). 
das imagens deve induzir a esses nugae. Para cada virtude e para cada pecado há um exemplo tirado dos bestiários, e os animais tornam-se figuras do mundo humano" (ECO, 1989, p. 87).

De fato, por volta do séc. XII, pelo intenso movimento intelectual que se deu, ressurgiu nova discussão sobre a admissibilidade do riso. Alguns que se dedicavam à educação começaram a ver nesse ato humano um potencial educativo e, por isso não hesitavam em servir-se de cenas ou palavras cômicas como instrumentos ou recursos para a transmissão da mensagem cristã. ${ }^{10}$ Em função disso, pequenos textos humorísticos poderiam ser inseridos até mesmo nos sermões e, desse modo, o riso era utilizado para execrar os comportamentos reprováveis e ridicularizar pecadores, fazendo valer a máxima "ridendo castigat mores". ${ }^{11}$

É justamente dessas duas abordagens do riso magistralmente descritas no romance que o artigo pretende se ocupar. Jorge de Burgos representa aquela tradição que proíbe o riso, porém, não podendo evitar que surjam outros que não convencidos por tais ideias, visto reconhecer que rir é inerente ao ser humano, começa a aterrorizar os que riem. À semelhança do tribunal do "Santo Ofício” almeja purificar o homem do seu pecado, eliminando o pecador. O franciscano Guilherme de Baskerville, que defende o velho princípio de que "rir é próprio do homem", é retratado como um frade de ideias avançadas, adepto da lógica e das experiências, divulgador das doutrinas de Roger Bacon, Guilherme de Ockham e Marsílio de Pádua, e que levava, em suas viagens determinados instrumentos que ampliam a própria razão, como as lentes, que o autor dá um nome sofisticado (vítreos "ab oculis ad legendum”) e a bússola que é descrita como a máquina "capaz de reconhecer o setentrião de noite e em lugar fechado, sem poder enxergar nem o sol em, nem as estrelas" (ECO, 1989, p. 222). E que nem mesmo Roger Bacon teria possuído uma igual.

10 A Hugo de S. Vitor, por exemplo, é atribuída a frase "quia aliquando plus delectare solent seriis admixta ludicra” (algumas vezes as brincadeiras costumam agradar mais, misturadas às coisas sérias). (apud CURTIUS, 1957, p. 441).

11 Essa máxima bastante conhecida não é tão antiga, ainda que seja discernível em "ridentem dicere verum”, de Horácio, que aparece no início de suas Sátiras (I, 1, 24). Teria sido cunhada por Jean de Santeuil (séc. XVII) a propósito da máscara de Arlequim, cujo busto decorava o proscênio da Commédie Italienne, de Paris. 


\section{Jorge de Burgos e o interdito do riso}

O conservadorismo de Burgos fica transparente quando observa que, naquela abadia, há muito, serpenteava o áspide do orgulho. Não o da riqueza, pois a verdadeira riqueza para o beneditino seria o trabalho. Mas algo que ia além do que, segundo ele, competia aos monges: custodiar o saber. Em outras palavras, em vez da busca da verdade, que representaria esse orgulho referido, deveriam seus confrades apenas conservar o saber.

A custódia, digo, não a busca porque é próprio do saber, coisa divina, ser completo e definido desde o início, na perfeição do verbo que exprime a si mesmo, A custódia, digo, não a busca porque é próprio do saber, coisa humana por ter sido definido e completado no arco dos séculos que vai desde a pregação dos profetas à interpretação dos padres da igreja. Não há progresso, não há revolução de períodos na história do saber, mas, no máximo, contínua e sublime recapitulação” (ECO, 1989, p. 412).

É bom lembrar que, no cristianismo do séc. IV, os monges eram tidos na condição de extensão da milícia celeste em oposição às hostes demoníacas. Deveriam constituir-se num espaço impenetrável para o demônio e, por isso mesmo, deveriam entregar-se, além do trabalho, a jejuns, orações e outras formas de mortificação, concretizando o ideal de renúncia ao mundo. Ao mesmo tempo, para sustentar tal postura por um discurso justificador, os mosteiros cedo se transformaram num repositório do saber, conservando, na antiguidade tardia e em todo o período medieval, a cultura antiga. Em outras palavras, a vida monástica só teria sentido se houvesse total dedicação a algo relevante e sério, não havendo, portanto, lugar para a brincadeira. Daí Umberto Eco mostrar o quanto era fundamental a existência de uma biblioteca nos mosteiros. Nesse sentido, põe nos lábios do abade esta afirmação: "Monassterium sine libris est sicut civitas sine opibus, castrum sine numeris, coquina sine supellectili, mensa sine cibis, hortus sine herbis, platum sine floribus, arbor sine foliis [...]” (ECO, 1989, p. 43). (Um mosteiro sem livros é como uma cidade sem riquezas, um quartel sem tropas, uma cozinha sem utensílios, uma mesa sem comida, um jardim sem plantas, um prado sem flores, uma árvore sem folhas [...]).

Há uma tradição exegética que enfatiza o caráter privilegiado do mosteiro, comparando-o a uma espécie de antecipação do destino que teriam os monges post-mortem. Porém, em vida, o mosteiro seria um território de ação, de exercício das atitudes que garantiriam lugar do monges nesse "claustro celeste”. Daí a severa normatização da vida monástica. 
Burgos defende que o próprio Jesus, em suas parábolas, não procurou levar o homem ao riso. E, se Adelmo, com suas ilustrações, procurava retratar o risível, de certo modo, recebeu o que merecia, "pois gozava totalmente com as monstruosidades que miniaturava”. Daí sua voz solene e ameaçadora, ao afirmar que o ilustrador percorreu todos os atalhos da monstruosidade e Deus, em situações tais como essa, sabe punir (ECO, 1989, p. 89).

Afirma que as comédias foram escritas pelos pagãos para levar os espectadores ao riso e, nisso, fizeram mal. Afinal, nosso Divino Mestre jamais se serviu de tal gênero. As parábolas seriam límpidas metáforas para, alegoricamente, servir de instrução para que se possa alcançar o paraíso (ECO, 1989, p. 139). O riso faz mal ao próprio corpo. Se os banhos curam os humores e as afecções do corpo, especialmente a melancolia, "o riso sacode o corpo, deforma as linhas do rosto, torna o homem semelhante ao macaco" (ECO, 1989, p. 139). Nesse contexto, não é desprovida de razão a observação de Le Goff (2000, p. 72): "A codificação do riso e a sua condenação nos círculos monásticos resultam, ao menos em parte, de sua perigosa relação com o corpo.”

Relembrando o velho dito aristotélico, replica que nem tudo o que é próprio do homem é necessariamente bom (ECO, 1989, p. 139). Afinal, quem ri, não acredita naquilo do que está rindo e, por outro lado, tampouco o odeia. É sinal de estultice, visto que aquele que ri do mal não está disposto a combatê-lo. Além disso, desconhece a força através do qual o bem se propaga. "O ânimo é sereno somente quando contempla a verdade e se deleita com o bem realizado, e da verdade e do bem não se ri. Eis por que Cristo não ria. O riso é incentivo à dúvida” (ECO, 1989, p. 140).

O fundamento histórico desse princípio de que Jesus jamais teria rido seria o fato de que, nos evangelhos, não há qualquer descrição em que o Mestre apareça esboçando uma atitude dessa natureza. É verdade que proferiu lamentação ao contemplar Jerusalém, chorou junto ao túmulo de Lázaro, agonizou no Getsêmane, assumindo, desse modo, a condição humana, mas os evangelhos não registram o Mestre rindo ou provocando o riso.

Eco, sabiamente levanta o problema já suscitado por João de Salisbury ${ }^{12}$, ao reportar a uma questão de princípio. Se o rir é próprio do homem, dessa natureza também participa o Deus-homem. Daí a interrogação: terá ele rido alguma vez? Haveria uma alegria especificamente santa? São interrogações levantadas por Pedro de Cantor, em seu Verbum Abreviatum: "Sed num quid

12 Policraticus I, 305, 8ss, onde se alude a uma carta apócrifa de Lêntulo. Este autor faz concessão a uma modesta hilaritas, de tempos em tempos, desde que tudo transcorra com decência. 
potuit Deus bene risisse? Videtur quidem quod habita causa interiore laetitia bona, quod eam exterius in opere ridendi monstrare possit, máxime cum omnes defectus nostros praeterquam caulpae assumpserit; etiam cum risibile, vel risibilitas, proprium sit hominis a natura datum” (Mas será que Deus pode ter rido de verdade? Parece que havendo uma causa íntima, (existia) nele uma alegria boa que pôde externar no ato do riso, sobretudo por ter assumido todos os nossos defeitos, exceto a culpa; tanto mais que o risível ou a risibilidade é uma característica do homem, dada pela natureza) (CURTIUS, 1957, p. 442). Le Goff (1992, p. 72) parece estabelecer uma síntese dessa antiga teoria. Se Jesus não riu uma única vez em sua vida humana, justamente ele que é o grande modelo humano, o riso torna-se estranho ao homem, ou pelo menos ao homem cristão. Mas se, por outro lado, é dito que o riso é o próprio do homem, ao rir, o homem estará exprimindo, com toda certeza, o melhor de sua natureza. ${ }^{13}$

Há uma interrogação de Baskerville a Jorge que merece ser citada: “Mas o que te assustou nesse discurso sobre o riso?” (ECO, 1989, p. 487). A resposta do velho monge é incisiva. Fundamenta-se no fato de ser o misterioso livro uma obra filosófica. Eis a razão do temor do velho bibliotecário. Embora houvesse muitos outros livros que tenham abordado a comédia e muitas outras obras que falem sobre o elogio do riso, o medo está centralizado no fato de tal livro ter conteúdo filosófico. Ou, nas palavras do próprio ancião "Porque era do Filósofo. Cada livro daquele homem destruiu uma parte da sabedoria que a cristandade acumulara no correr dos séculos” (ECO, 1989, p. 487).

Diante da réplica de Guilherme de que ele poderia não estar eliminando o riso ao eliminar o livro, responde "Claro que não" E continua:

O riso é a fraqueza, a corrupção, a insipidez de nossa carne. É o folguedo para o camponês, a licença para o embriagado, mesmo a igreja em sua sabedoria concedeu o momento da festa, do carnaval, da feira, essa ejaculação diurna que descarrega os humores e retém de outros desejos e de outras ambições... (ECO, 1989, p. 487).

O riso não só teria o poder de suspender a razão como de desarmála. Na linguagem de Jorge de Burgos, liberta o indivíduo do medo do demônio, tornando-o vulnerável às suas armadilhas. Se o homem tiver a liberdade de rir, isso poderá levá-lo a afrontar a autoridade instituída e, talvez, o próprio Deus.

13 (ALBERTI, 1999, p. 69). LE GOFF, Rire au Moyen Age. Cahiers du Centre de Recherches Historique, n. 3, p. 1-14, avril 1989 (École des Hautes Études en Sciences Sociales). 
Parte-se do princípio de que toda religião fundamenta-se no temor. De modo paradoxal, o crente ama e teme a divindade. ${ }^{14}$ Assim, o temor é fundamental, e quem ri tende a não temer. $\mathrm{O}$ argumento de Burgos é expresso desta maneira:

$\mathrm{O}$ riso libera o aldeão do medo do diabo, porque na festa dos tolos também o diabo aparece pobre e tolo, portanto controlável. Mas este livro poderia ensinar que libertar-se do medo do diabo é sabedoria. Quando ri, enquanto o vinho borbulha em sua garganta, o aldeão sente-se patrão, porque inverteu as relações de senhoria... (ECO, 1989, p. 488). para contradizê-lo:

Nesta linha de argumentação, Burgos cita Aristóteles, porém,

Que o riso é próprio do homem é sinal do nosso limite de pecadores. Mas deste livro quantas mentes corrompidas como a tua tirariam o silogismo extremo, pelo qual o riso é a finalidade do homem! O riso distrai, por alguns instantes, o aldeão do medo. Mas a lei é imposta pelo próprio medo, cujo nome verdadeiro é temor a Deus (ECO, 1989, p. 488).

Por isso, justifica o cuidado que teve em esconder o famoso livro:

[...] E deste livro poderia partir a fagulha luciferina que atearia no mundo inteiro um novo incêndio: e o riso seria designado como arte nova, desconhecida até de Prometeu, para anular o medo. Para o aldeão que rir, naquele momento, não lhe importa morrer: mas depois, acabada sua licença, e a liturgia impõe-lhe de novo, de acordo com o desígnio divino, o medo da morte. E deste livro poderia nascer a nova e destrutiva aspiração a destruir a morte através da libertação do medo. E o que queremos nós, criaturas pecadoras, sem o medo, talvez o mais benéfico e afetuoso dos dons divinos? (ECO, 1989, p. 488-789).

Em síntese, para o velho monge, o riso torna profano o sagrado. Quando rimos, no fundo, estamos rindo de nosso medo e das nossas crenças; logo, levantando dúvidas sobre a fé. Além disso, o riso questiona verdades absolutas, dogmas estabelecidos e autoridades impostadas. Desse modo, o fiel religioso deve, de todos os modos, evitar o riso.

14 (OTTO, 1985). Nesta obra, faz-se referência ao duplo sentido do sagrado: o fascinosum e o mysterium tremendum, ou seja, o lado divino que fascina e atrai e o lado divino que infunde o medo. 
Não temos elementos históricos para afirmar que o cristianismo primitivo era totalmente contrário ao riso, como faz o velho bibliotecário. Embora o apóstolo tenha proibido aos cristãos de Éfeso stultiloquium e scurrilitas (palavras tolas e chocarrices) ${ }^{15}$, aconselha aos cristãos de Filipos: “Alegrai-vos sempre no Senhor; outra vez digo, alegrai-vos!”16 Talvez muitos, no tempo do apóstolo pensassem ser a alegria incompatível com a vida voltada para Deus e imaginassem um protótipo de cristão extremamente sério, carrancudo, fechado em si, que nunca brinca e, muito menos, ri.

Se, na tradição filosófica o homem é um ser que ri, ou melhor, o único que ri, fazendo uma transposição para o plano teológico, podemos concluir que, sendo ele a imagem de Deus, o riso só pode ser um “atributo” divino. Se não explicitamente, pelo menos de modo implícito, podemos dizer que este princípio foi adotado nos primeiros anos do cristianismo.

Porém, com o passar do tempo, o riso passou a associar-se à falta de pudor e, no plano ritual, era visto como associado aos cultos pagãos idolátricos, supostamente pecaminosos. Isso, evidentemente, contribuiu de modo decisivo para a desconfiança dos teólogos cristãos quanto ao seu valor e utilidade. ${ }^{17}$

José Rivair de Macedo, em obra que representa extensa pesquisa sobre o riso na Idade Média, analisa os valores a ele atribuídos, desde a sacralização clássica até a condenação pelos órgãos eclesiásticos. Dele transcrevemos esta afirmação:

Dentro dos sistemas de valores cristãos, o lugar ocupado pelo riso sofreu importantedeslocamento, em primeiro lugar pelo fato de que daí em diante seus índices de sacralidade passaram a ser negados. De fato, os pensadores da Igreja dessacralizam o riso, banindo-o das formas aceitas do culto religioso e da liturgia. Além disso, atribuíram-lhe caráter demoníaco, associando-o às fraquezas do corpo e, portanto, ao pecado. (MACEDO, 2000, p. 250-251).

Os polemistas cristãos, em virtude da natureza da crença que professavam, não reconheceram qualquer grau de sacralidade no riso, o que gerou certa desconfiança em relação ao mesmo. Vivendo numa sociedade em que o domínio da escrita seria privilégio de poucos letrados, os gestos e as palavras tinham extrema relevância. Chegou-se a pensar que, no corpo, haveria secretos movimentos do espírito que, escondidos no interior de cada pessoa, podiam, em determinados momentos, manifestar-se.

15 Ef. 5.4.

16 Fp. 4.4.

17 Para a dessacralização dos mitos antigos e sua interpretação segundo as premissas cristãs, SCHMITT, 1990, p. 45-46). Recomenda-se também o excelente artigo de (MACEDO, 1997, p. 87-110). 
Os apologistas, buscavam na Bíblia ${ }^{18}$ os modos de conduta que deveriam acompanhar os bons cristãos, pois, até o séc. XIV, ela era considerada o livro do qual se tiram referências teóricas e regras práticas. Daí o fato de passarem a adotar a sobriedade e a continência, fazendo com que ambas as virtudes ascendessem na escala de valores defendida pelo cristianismo. Afirmando o controle do espiritual sobre o físico, condenou-se qualquer tipo de impulso desordenado. A prece, em clima de solidão, passou a opor-se às tendências que levavam ao riso. A vigilância sobre si mesmo deu lugar a um modo contido de se ver e apreciar as coisas, descartando, sempre quando possível, o riso. Ao observarem as religiões pagãs, alguns Pais da Igreja perceberam nelas a dimensão ritual do riso e, assim, não tardaram em estabelecer não apenas o contraste, mas envidaram esforços para a dessacralização do riso. Assim, o ato de rir passou a ser considerado gesto puramente profano e, obviamente, carregado de conotações negativas (MACEDO, 1997, p. 101). Em face da sobriedade e da continência moral, ambas consideradas virtudes inerentes à vida cristã, o riso tornou-se indecente.

Clemente de Alexandria (1960, p. 99, c. 150-215 d. C.), um dos primeiros escritores cristãos a apropriar-se de elementos da filosofia grecoromana para a elaboração do discurso cristão, no longo tratado que passou a ser conhecido como Paedagogus,${ }^{19}$ Cristo é invocado como o grande educador, mestre de todos os fiéis. A obra divide-se em três livros e dirige-se a um público de batizados com o objetivo de ensinar uma vida coerente com a condição cristã, precedendo a formação do conhecimento. O primeiro estabelecia princípios gerais e os dois últimos constituíam-se de um repertório de regras práticas de moral para todas as circunstâncias da vida. Buscando fundamentos nas Escrituras, em Platão, em Aristóteles, em Sêneca, etc. aborda o ato de comer e beber, a escolha e disposição do mobiliário, o procedimento nos banquetes, o uso de perfume e, evidentemente, a questão do riso e a necessidade de se evitar obscenidades. As instruções, como se pode observar, são detalhadas e destinam-se, ao que parece, a cristãos abastados. Portando, evocando o amparo bíblico e dos sábios gregos, o referido autor elaborou uma série de preceitos educativos abrangendo a conduta espiritual e os atos corriqueiros do cristão. Na parte dedicada aos comportamentos desejáveis dos fiéis, aborda a

18 Sobre o riso na Bíblia, (VOELTZEL, 1955).

19 Na sociedade helenística, pedagogo era, originariamente, um escravo que, conforme e etimologia, tinha por dever conduzir a criança, acompanhando-a até a escola, protegendo-a dos perigos e ensinado-a a se comportar. Estava sob seu cargo o cuidado completo da boa conduta moral, enquanto que, ao mestre, cabia a instrução. 
questão do riso, afirmando que seus amantes não poderiam ser incluídos na comunidade cristã (DEMPF, 1958, p. 54). As palavras ridículas deveriam ser desprezadas, pois o pensamento, revela a essência do homem e, à medida que se usa palavras "baixas"20, afasta-se das alturas do céu.

Reproduzindo a literatura sapiencial hebraica, Clemente considera o riso comedido como atitude do sábio; contudo, se desmesurado deveria ser considerado semelhante o riso das prostitutas (kichlismos) ou, então, o riso dos proxenetas (kanchasmos). Nessa linha de pensamento, não seria aconselhável rir a todo o momento, nem demoradamente. Era preciso distinguir os momentos e as circunstâncias em que o ato de rir poderia manifestar-se, sem ser considerado ofensa a Deus. ${ }^{21}$

A posição de Clemente poderia ser julgada como moderada, oscilando entre a negação e a incorporação do riso ao ideário cristão. ${ }^{22}$ Igualmente moderada é a tendência de Agostinho (354-430 d. C.). Embora nas Confissões ${ }^{23}$ advertisse sobre o perigo do riso efêmero, que poderia distanciar o fiel de Deus, num texto destinado à formação de pregadores, aconselhava algumas precauções nos discursos dirigidos a principiantes ou leigos. Entre essas precauções estavam a de se evitar que as palavras provocassem aversão, cansaço ou bocejos. Também deveriam ser empregadas palavras simples, de fácil compreensão para os neófitos. E, principalmente, no que diz respeito ao tema que estamos tratando, a mensagem cristã deveria ser transmitida com bom humor. Nesse caso, era permitido valer-se até mesmo do riso para que a mensagem infundisse paz na alma e despertasse o interesse dos ouvintes (SAINT AUGUSTIN, 1949, p. 54-80).

20 Isso certamente contribuiu para que a oposição em vigor na Idade Média não fosse entre a esquerda e a direita, como em nossos dias. Era sobre o alto e o baixo ou, então, sobre o interior e o exterior. O riso procede do ventre, portanto, da parte "baixa” do corpo, em comparação com a cabeça, a parte alta. A Regula Magister, na qual se inspirou a Regra de São Bento, fala que o riso caminha através do corpo, provindo das partes baixas, passando pelo peito e pela boca. O riso seria uma "desonra da boca" e a boca deve funcionar como "ferrolho" (LE GOFF, 2006, p. 75).

21 Por exemplo, era desaconselhável rir na presença dos mais velhos, de pessoas a quem se devia respeito, ou de estranhos.

22 As exortações de Clemente têm como pano de fundo a vida de Alexandria, metrópole opulenta que, aos olhos do autor, revestia-se de luxo e dissolução. Não visava propriamente a um ideal ascético, nem á renúncia de todas as alegrias e satisfações mundanas. Sua preocupação era advertir para que os fiéis não se deixassem subjugar pelas paixões, mantendo tudo sob justa medida.

${ }^{23}$ Conf., II, 9. 
Outra vertente importante do Cristianismo, também preocupada com o riso e a risibilidade, era constituída pelos cenobitas, que viriam a exercer extraordinária influência na formação do ascetismo medieval. De Antão, informa Atanásio não ser ele propriamente um melancólico, nem um turbulento no uso da alegria e, segundo consta, não precisava lutar contra o riso (CURTIUS, 1957, p. 440). Segundo o autor, o referido santo era "condimentado com o divino gracejo", como, aliás Paulo recomenda na carta aos Colossenses: "sermo vester semper in gratia sale sit conditus" (seja a vossa palavra sempre temperada com o sal da graça). ${ }^{24}$

Contudo, na Instituta Monachorum Sancti Basilii, mais conhecida como Regra de São Basílio, redigida no ano 365, nas proximidades de Cesareia, encontramos os primeiros argumentos contrários ao riso. Isso viria a se firmar nos séculos seguintes, dentro do que se convencionou chamar "paradigma monástico”. A Regra, desenvolvida em forma de diálogo, aponta certas reflexões concernentes ao modo de conter o riso, pois ser dominado pelo riso imoderado é sinal não só de intemperança, como de intranquilidade, e tal atitude denota o relaxamento espiritual. Porém, o riso sereno, por mostrar a expansão da alma, não é por si mesmo inconveniente. O problema, portanto, dizia respeito ao grau de intensidade das emoções, ou seja, referia-se à demonstração de que o fiel pode ou não ser capaz de controlá-la. Mas esta recomendação parece pouco flexível: "Como o Senhor condena os que riem agora, é evidente não haver para o fiel tempo algum próprio ao riso, principalmente sendo tão grande a multidão dos que ofendem a Deus, por violação da lei, e morrem no pecado; por todos eles devemos contristar-nos e gemer” (MAGNO, 1983, p. 76).

Porém, opondo-se a atitudes conciliatórias em relação ao riso, podemos citar posições bem mais extremadas, cujo principal representante veio a ser, no início do século V, João Crisóstomo, que se tornou Bispo de Constantinopla. Considerava a vida monástica segura e mais calma que a sacerdotal, apontando a primeira como mais elevada na escala da perfeição. Embora se servisse do gênero do tratado, o que mais se destacam são suas homilias, de conteúdo teológico, catequético, moral e litúrgico. Seus ensinos tornaram-se célebres na antiguidade tardia e na Idade Média bizantina a ponto de ser considerado um dos padres ideais da Igreja do Oriente. Procura mostrar que os fundamentos da repulsa em relação ao riso provinham diretamente da leitura dos textos do Novo Testamento, e a condenação apresentada era vazada num estilo de grande truculência. Comentando determinada passagem da epístola

${ }^{24}$ Col. 4.6. 
aos Hebreus, afirmou que a via da purificação seria através do choro, pois, para que se pudesse rir na vida eterna, era necessário chorar neste mundo. ${ }^{25}$ Eco, no seu romance, pelos lábios de Jorge de Burgos, atribui a Crisóstomo (no texto, Giovanni Boccadoro) a afirmação de que Cristo nunca riu (ECO, 1989, p. 103), o que não contraria a tradição.

Vivendo numa época em que os valores do mundo clássico perdiam sua força diante da profunda crise social, econômica, política e espiritual que cercaram os momentos finais de agonia do Império Romano, este pai da Igreja mostrou-se bastante reticente em relação aos costumes dos seus contemporâneos, pregando, com entusiasmo, a necessidade de contrição e renúncia aos deleites da vida mundana. Para o eloquente pregador (daí o nome Crisóstomo, "boca de ouro"), era preciso varrer o riso do comportamento dos leigos e dos que integravam os diversos segmentos institucionais da Igreja.

Porém, como seria impossível à Igreja eliminar o riso, houve a necessidade de admiti-lo sob certas condições e de interditá-lo naquilo que pudesse afrontar a verdade instituída. A resposta da tradição teológica medieval a este dilema será a diferenciação entre dois gêneros de alegria: a laettitia e o gaudum spirituale. Verena Alberti (1999) vê nessa divisão uma forma de se classificar o riso. Porém, isso é discutível e sua conclusão parece um tanto simplista:

O primeiro correspondia à felicidade das coisas terrenas e passageiras, que fazia com que o homem esquecesse sua missão. O segundo, em compensação, era a verdadeira felicidade, aquela que atingia sua maior realização após a morte, mas podia ser experimentada ainda em vida, pela contemplação de Deus e de suas criações. A esta última correspondia o riso discreto e mudo que exprimia a felicidade do coração”. (ALBERTI, 1999, p. 69).

Para ser coerente em relação ao contexto em que Umberto Eco situa seu romance e o local em que se tece o enredo, é preciso lembrar a Regulam Sancti Benedicti ${ }^{26}$ que, redigida no séc. VI para ser aplicada ao

25 St. Jean Chrysostome, Homélies sur l'épitre aux Hebreux. In Oeuvres completes. Tradução de J. Bareille. Paris: Louis Vives, 1873, tome XX, p. 284 (apud MACEDO, 1997, p. 104).

${ }^{26}$ Como sublinha Adalbert de Vogué, a diferença entre a Regra Beneditina e a Regula Magister reside no fato de que esta última é mais subjetiva, com vasta utilização de metáforas, enquanto que a primeira é mais prática, ou seja, mais objetiva (VOGUE, 1972, p. 221-222). Há um comentário da Regulam Sancti Benedicti traduzido para nossa língua que pode ser consultado (HERWEGEN, 1953, p. 115-146). 
Mosteiro de Monte Cassino, acabou sendo acolhida por outros mosteiros, tornando-se referência no que concerne aos princípios orientadores dos religiosos em geral. A regra partia do princípio de que aquele que abraça a vida monástica, como já citado anteriormente, separa-se do mundo e, quanto mais se guarda silêncio, mais se fala interiormente com Deus. A proibição das palavras que provocam riso tem sua justificativa, visto que os gracejos frívolos e as conversas ociosas e provocadoras de riso eram tidas na conta de algo que perturba a dedicação incondicional a Deus.

No capítulo VI da Regra, cuja denominação é "De Taciturnitate” (Do silêncio), há uma exortação para o exercício do mais completo isolamento. Do mesmo modo que no deserto, no cenobium deve o monge continuar a ser um solitário. A palavra, signo da união pela comunicação, deve ser restringida, pois aqueles que habitam uma comunidade monástica separam-se da relação com o mundo. Guardar silêncio na companhia dos homens permite que se possa falar interiormente com Deus. A restrição é muito mais categórica quando se trata de palavras capazes de suscitar o riso: "Os gracejos frívolos e as palavras ociosas e provocadoras de riso condenamo-las a serem excluídas para sempre de todos os lugares e não permitimos ao discípulo abrir a boca para tais conversas”27. Os monges não deveriam sequer abrir a booca para tal prática. O riso seria a dissolução da rígida disciplina a eles imposta

Portanto, na perspectiva monacal ou na concepção dos formuladores da doutrina cristã, o riso costumava ser tomado, em alguns casos, como fator de indisciplina espiritual. Como dizia Alexandre Herzen, "Ria-se às gargalhadas até Luciano. Desde o séc. IV, os homens deixaram de rir, e começaram a chorar sem parar e pesadas correntes se apoderaram do espírito entre as lamentações e os remorsos de consciência” (BAKHTIN, 1993, p. 80, nota 34).

\footnotetext{
27 "Scurrilitates vero vel verba otiosa et risum moventia aeterna clusura in omnibus locis damnamus et ad talia eloquia discipulum aperire os non permittimus”. (ENOUT, 1990, cap. VI) Cf; S. P. Benedicti Regula cum commentariis. In: J. P. Migne, PL LXVI, col 350.
} 


\section{Guilherme de Baskerville o princípio aristotélico "rir é próprio do homem"}

Inicialmente, recordemos a vertente desta questão, a saber, a consideração do riso como próprio do homem. Obviamente, isso merece um repertório filosófico, pois o próprio integrava um dos cinco predicáveis, ou seja, uma das cinco classes de predicados, a saber: o gênero, a espécie, a diferença, o próprio e o acidente ${ }^{28}$.

Aristóteles assim caracteriza o próprio: “[...] é o que, sem exprimir a essência do sujeito, só a este pertence, de maneira que é com ele convertível; por exemplo, é próprio do homem aprender gramática, porque se A é homem, é capaz de aprender gramática, e se é capaz de aprender gramática é homem.”29

Na Isagoge ${ }^{30}$, Porfírio (1965, p. 233-340) não só retomou como procurou sistematizar as indicações do estagirita. No cap. IV do referido livro, encontram-se quatro sentidos do próprio:

a) o que designa o predicado que convém a um única espécie, mas não a toda ela;

b) o que designa o predicado que cabe a toda a espécie, embora não seja exclusivo dela;

c) o que indica o predicado que convém a uma única espécie, a toda ela, mas não sempre;

d) o que indica todas as condições ao mesmo tempo: ser de uma só espécie, de toda, e sempre.

Como exemplo do primeiro sentido de próprio pode ser lembrado no homem o fato de o mesmo poder conhecer a medicina ou conhecer a geometria. Como exemplo do segundo, Porfirio cita o ser bípede, para o homem. Como exemplo do terceiro, é citado o encanecer na velhice, novamente em relação ao homem. E, finalmente, como exemplo do quarto, Porfírio cita a capacidade de rir para o ser humano. E justifica:

28 Tópicos, I, 5-6. cf. também V, 1ss.

29 Tópicos, I, 5 102a 17-23.

30 Assim é conhecido no Ocidente o livro Introdução às Categorias de Aristóteles (Eisagogè eis tàs kategorías), que mereceu vários comentários em grego e foi traduzido para o latim por Mário Vitorino e Boécio. Este último também comentou o tratado das Categorias, de Aristóteles. 
[...] mesmo que ele não ria sempre... ao menos se diz que ele é capaz de rir, não porque ri sempre, mas porque pode fazê-lo naturalmente; é uma qualidade que faz sempre parte de sua natureza, como para o cavalo a faculdade de relinchar. Estas últimas qualidades são com justiça chamadas próprias, porque elas reciprocam também com o sujeito: se há cavalo, há faculdade de relinchar, e se há faculdade de relinchar, há cavalo" (PORFIRIO, 1965, p. 18-23). ${ }^{31}$

Nos Tópicos, Aristóteles aponta como exemplo de próprio, para o homem, a capacidade de aprender gramática, como já foi citado. No famoso texto que os antigos latinos conheciam como De Partibus Animalium (Das partes dos animais), afirma o filósofo que o riso é o elemento que distingue o homem dos outros animais. No texto, encontramos importantes observações sobre os aspectos fisiológicos do riso. Ao deter-se no diafragma, escreve Aristóteles: “Que apenas os entes humanos são suscetíveis às cócegas é devido à finura de sua pele e ao fato de que os entes humanos sejam os únicos animais que riem"32.

A divulgação dessa ideia chegou até nós de diversos modos, como esta, por exemplo: “Aristóteles ensina que o riso é algo próprio do homem. O senhor ri; logo, o senhor é um homem. Fez bem em rir, pois do contrário não nos teríamos apercebido disso” (JEKOVIC, 1970, p. 47).

No período posterior a Aristóteles, muitos voltaram a essa afirmação. Luciano de Samósata ${ }^{33}$ é um bom exemplo. Tendo vivido no séc. II d.C., é um dos pensadores gregos mais importantes da Antiguidade Tardia. Escreveu cerca de 80 obras, a maioria de caráter satírico, pretendendo, em seus escritos, servir ao leitor "riso sob filosofia". Isso quer dizer que põe a sátira a serviço da atitude filosófica, na linha do antigo cinismo. Sua influência estende-se a autores como Thomas Morus, Rabelais, Cervantes, Maquiavel, Diderot, Voltaire, etc. É conhecida do autor a afirmação de que a distinção entre um homem e um asno está no fato de o primeiro ser dotado de riso. E afirma, ainda, que o asno se difere do homem porque não constrói casa nem navega.

31 A questão é retomada no final do cap. V, quando se compara o próprio e o acidente.

32 De partibus animalium, III, 10, 673a 5-10. Na Loeb Classical Library, edição de 1983, a obra encontra-se no volume 12.

33 Do autor, temos em português, as seguintes obras: SAMÓSATA, 1973; Uma história verídica. Trad. Custódio Magueijo. Lisboa: Inquérito, 1989; Diálogos dos mortos. Trad. Maria Celeste Consolin Dezotti . São Paulo: Hucitec, 1996; Hermótimo ou as escolas de filosofia. Trad. Custódio Magueijo. Lisboa: Inquérito, 1996. 
E, por falar em asno, Apuleio, escritor latino também do séc. II d. C., nascido em Madaura, na Numídia, portanto, conterrâneo de S. Agostinho, em seu conhecido romance de aventuras e costumes, Metamorphoseon ou Asinus Aureus, ao descrever o protagonista Lucius, que acaba sendo involuntariamente metamorfoseado em asno, faz com que as cenas subsequentes apresentem aspectos caricaturescos e estimuladores do riso. Mesmo antes dessa metamorfose, o dito personagem, sem saber, participa de uma encenação cômica anual na cidade de Hypata, cujo deus protetor é Risus. ${ }^{34}$

Posteriormente, entre os autores humanistas, destacamos Castiglione que, em $O$ Cortesão, enfatiza que "o riso é observado apenas na humanidade, e é sempre sinal de uma certa jovialidade e um certo ânimo alegre que o homem sente no interior de sua mente" (SKINNER, 2002, suplemento Mais).

E já que ultrapassamos a Idade Média, não deve ser esquecida a contribuição de Rabelais (1494-1553). Sua crônica Gargantua começa com um pequeno poema de dez versos que, na tradução de Aristides Lobo, assim aparece:

Caros leitores que este livro vedes,

Libertai-vos de toda prevenção;

E não vos melindreis, ó vós que o ledes,

Que nenhum mal contém, nem perversão.

É verdade que pouca perfeição,

Salvo no riso, aqui podeis obter:

Outra coisa não posso oferecer,

Ao ver as aflições que nos consomem;

Antes risos que prantos descrever,

Sendo certo que rir é próprio do homem (RABELAIS, 1986, p. 39).

O referido autor, abraçando o riso como método clínico, apresenta um phármakon que procura eliminar a tristeza que cerca o homem, especialmente o homem medieval, quase sempre atemorizado pelo fogo do inferno e atormentado pelo pecado, mensagem institucional que recebeu não só da Igreja como da família. Esse estado de espírito tristonho só pode ser vencido pelo riso. Desse modo, Bakhtin percebe uma integração entre a medicina e a

34 (APULEIO, 1960, p. 57-62). Conforme a cultura, o asno assumiu dimensão mítica, especialmente em rituais de fecundidade, apresentando-se dotado de um apetite sexual voraz. Contudo, a exacerbação desse desempenho sexual levava-o a determinados fracassos que passavam a ser objetos de riso. Aliás, as linhas narrativas do romance de Apuleio ancoram-se nesses dois aspectos, a saber, o desejo sexual exagerado e a tolice. 
arte, mas não apenas nos termos tradicionais que integram o comediante e o vendedor de drogas farmacêuticas. Antes, o autor proclama, sem qualquer rodeio, a virtude curativa da literatura (no caso, as crônicas), que proporciona a distração e faz rir. A virtude curativa do riso é afirmada por Rabelais, ao referir-se à doutrina de Hipócrates, Galeno, Platão e outras autoridades (BAKHTIN, 1993, p. 58, 139). Enfatiza que, através da brincadeira, é perfeitamente possível afastar a angústia e eliminar a tensão. ${ }^{35}$

Gargantua é, por certo, um personagem emblemático da Idade Média, fruto da alegria proporcionada pelo grotesco encontro de Grandgousier com Gargamelle. Os dois costumavam brincar de bicho de duas costas, esfregandose alegremente, quando ela ficou grávida de um lindo filho, que carregou consigo durante onze meses. É, portanto, filho de "um folgazão" com rapariga bonita e cara (RABELAIS, 1986, p. 55). Habita um mundo de transgressões na qual o homem e o animal se igualam no primado do instinto, estabelecendo, ainda que provisoriamente, a negação da ordem racional: "Comia na mesma tigela que os cachorrinhos do pai. Mordia-lhes as orelhas e eles lhe arranhavam o nariz; sopravalhes o cu e eles lambiam-lhe as bochechas”(RABELAIS, 1986, p. 86). Considera a bebedeira e a comilança não como vícios, mas como formas de fugir aos contratempos da vida. "Feliz não é quem cedo se levanta, mas quem cedo bebendo, o mal espanta” 'RABELAIS, 1986, p. 125). Ou, então: “Anunciemos, ao som das botijas e garrafas que quem tiver perdido a sede não tem nada a fazer aqui" (RABELAIS, 1986, p. 63). E ainda:”Beba sempre que não morrerá” (RABELAIS, 1986, p. 61). Prega um distanciamento necessário da vida séria e regrada para que se posssa ter uma conversa repassada de conclusões filosóficas, que traduzem experiências práticas na confraria desses bebedores.

Em síntese, para esses autores, o riso é uma qualidade que pertence excluisvamente ao homem. O morrer, por exemplo, não é algo que pertence só à espécie humana. Entretanto, os animais, que têm o instinto de conservação jamais poderão formular a proposição "Sócrates é mortal”. Só o homem tem consciência da morte, iminente e necessária no contexto da condição humana. Semelhantemente, o riso seria um modo de mostrar a contínua vulnerabilidade da vida por aquele que traz consigo a iminência da morte. É um modo de proteção da vida, mesmo considerando a inevitabilidade da morte; do contrário, a ideia de morrer seria sempre horrível.

35 A essa altura, é bom lembrar que Eco, através do herbarista Severino, lembra que "o limite entre o veneno e o remédio é bastante tênue, e os gregos chamavam a ambos de phármacon”, (ECO, 1989, p. 116). 
Contudo, para os pensadores medievais, o riso era um tema complexo, talvez mais complexo que para nós hoje. Embora fosse algo integrante do ser humano, como pudemos observar e isso fosse reforçado pela frase de um monge do séc. XI, "homo est animal rationale, mortale, risus capax" (o homem é um animal racional, capaz do riso) (KOLVE, 1966, p. 127), o riso foi considerado perigoso por aquilo que viesse a causar (KOLVE, 1966, p. 31). Na perspectiva monástica, o riso seria fator de indisciplina espiritual e, sob o ponto de vista leigo era condenado o excesso de alegria, visto que tal atitude poderia configurar numa despreocupação dos deveres mais elevados (CHELINI, 1968, p. 150).

Como assinala Le Goff, teólogos e moralistas cristãos da Idade Média apontaram as virtudes do "riso bom", que provoca felicidade e condenaram a desmesura das gargalhadas, associando-a a Satanás (LE GOFF, 2006, p. 65-82). Durante a Contra-Reforma, os censores da Igreja incluíram no Index livros humorísticos. A explicação era a de que tais livros seriam torpes, obscenos, lascivos, etc. Inácio de Loyola, o fundador da Companhia de Jesus, prevenia, nos acréscimos à primeira semana de seus Exercícios Espirituais: "Não ria e não diga nada que desperte o riso.” Não obstante tais proibições, a faculdade de rir, obviamente, jamais foi reprimida, ratificando a afirmação do estagirita, e o humor atravessou os séculos.

Certamente não é por acaso que encontramos em $O$ nome $d a$ rosa o franciscano Guilherme de Baskerville, firme nas suas convicções, lembrando o princípio aristotélico em diversas ocasiões (ECO, 1989, p. 83, 103, 139, 201, 204, 481). Fazendo uma comparação os homens com os símios, afirma: "Os macacos não riem, o riso é próprio do homem, é sinal de sua racionalidade" (ECO, 1989, p. 139). Ao enfrentar a tradição de que Jesus Cristo nunca riu, já aludida anteriormente, afirma que mesmo os teólogos repetiram a velha frase atribuída a Aristóteles. Afinal, como negar à essência aquilo que lhe é próprio? Os homens riram e vão continuar rindo por determinação da natureza. Se o estagirita dedicou especialmente ao riso o segundo livro da Poética, como imaginar que um filósofo de tal grandeza iria consagrar um livro todo a algo que não devia ser importante? (ECO, 1989, p. 120).

Baskerville partilha do princípio de que Deus quer que exercitemos nossa razão em muitas coisas obscuras nas quais as Escrituras nos deixaram livres para decidir. Afinal, quando alguém acredita numa proposição, ela deve ser aceitável, visto que a razão foi criada por Deus e aquilo que agrada nossa razão não pode deixar de agradar a razão divina. Desse modo, "para minar a falsa autoridade duma proposição absurda que repugna a razão também o riso pode ser um instrumento justo” (ECO, 1989, p. 141). 
E, notando que Jorge de Burgos, seu interlocutor, ao acusar a lenda sobre o martírio de S. Mauro de ridícula, muda de feição, observa: “Ainda que tacitamente e controlando vossos lábios, estais rindo de algo que quereis que eu também não leve a sério. Rides do riso, mas rides” (ECO, 1989, p. 141). E, nessas circunstâncias, Jorge parece capitular-se: "Brincando com o riso me arrastastes a discursos vãos". E, tentando voltar ao velho tema, sentencia: "Mas vós sabeis que Cristo não ria” (ECO, 1989, p. 141).

Recorrendo ao velho tema dos universais, Guilherme faz com que seu discípulo Adso de Melk progrida em seu raciocínio. Eis a interrogação: "Então, dizem lá em cima, todos os homens têm uma mesma forma substancial ou me engano?” "Certo”, respondeu o discípulo, orgulhoso. E emendou: “São animais, porém racionais e é próprio deles serem capazes de rir.” (ECO, 1989, p. 204).

Vai além: aponta a existência do risível até nos momentos extremos da vida. Para isso, evoca o martírio de São Lourenço, apontando para a frase que, segundo Ambrósio, teria sido pronunciada pelo mártir: "Manduca, iam coctum est" (Come, já está cozido). ${ }^{36} \mathrm{E}$ asseverava: "São Lourenço sabia, portanto, rir e dizer coisas ridículas, ainda que para humilhar seus próprios inimigos" (ECO, 1989, p. 103). Nesse mesmo sentido, lembra, ainda, o martírio de São Mauro (ECO, 1989, p. 141). Conta-se que os pagãos puseram água fervente e ele queixou-se de que o banho estava muito frio. $\mathrm{O}$ governador pagão, acreditando nas palavras do santo, enfiou totalmente as mãos na água para verificar se realmente estava frio e teria se queimado. Era um meio utilizado para ridicularizar os inimigos da fé.

O franciscano reconhece existirem os inimigos do riso. Seguindo sua tendência de explicar sempre os fenômenos pelas causas, comenta com Adso que o bibliotecário Malaquias, ao cumprir seu itinerário de trabalho (que incluía entrar na biblioteca e dela sair e, isso, diversas vezes ao dia, percorrendo um acesso proibido aos demais monges), não tinha motivação para o riso, visto que passava por um ossário. Daí a conclusão: “Ele... não tem do que rir" (ECO, 1989, p. 169).

Diante da tendência de se considerar o riso como manifestação diabólica, a contraposição de Baskerville é pertinente: “O diabo não é o príncipe da matéria. O diabo é a arrogância do espírito, a fé sem sorriso” (ECO, 1989, p. 492). E, demonstrando um notável espírito de piedade, dirige-se a Burgos,

36 (ECO, 1989, p. 103). Há outra tradição na qual São Lourenço, em cima da grelha, teria convidado os carrascos a virá-lo do outro lado. 
censurando-o pelo fato de ocultar o livro: "Deus criou os monstros também. Também te criou. E quer que se fale de tudo” (ECO, 1989, p. 492).

Isso tudo é indicativo de que a filosofia sempre se viu às voltas com o riso e as paixões por ele mobilizadas. No romance de Eco, é dito que Aristóteles, na Retórica, vincula o riso à zombaria e ao desprezo e, na Poética, afirma que o ridículo é uma forma do vergonhoso se manifestar, do feio se mostrar e do que é baixo aparecer. Observa-se também que nossa tendência é rir daquilo que é constrangedor e isso classificamos como inferior. Por isso que, quando rimos de alguém, estamos, com frequência, elevando-nos a nós mesmos, e isso nos torna superiores. Isso foi assumido por Hobbes que, no seu entender, "o riso é um orgulho que nasce da subita percepção de uma superioridade nossa (sudden glory) comparada à enfermidade dos outros ou à nossa fraqueza anterior." ${ }^{37}$

\section{CONCLUSÃO}

Como se viu, a discussão sobre o riso não é uma espécie de "terra virgem”, visto que ilustres nomes se ocuparam do assunto, enfocando o tema sob os mais diversos ângulos. Peculiar e característico do homem (e Bergson acrescenta que o homem é também o único que faz rir), desde os tempos remotos, houve uma preocupação em abordá-lo, mesmo em forma de contraposição como no caso a gargalhada de Demócrito e o pranto de Heráclito. Na Idade Média, por influência das ordens monásticas o riso tornou-se proibido em alguns redutos e somente no Renascimento haverá um despertamento pelo cômico e pelo risível, como bem refletem as obras de autores como Joviano Pontano, Castiglione, Escalígero, Francisco Valles, Gabriel de Tárrega, etc. e, sobretudo, do médico francés Laurent Joubert, autor de Traité du ris, datado de 1579.

Ao longo deste artigo, pode-se perceber que a literatura pode ter pertinente ligação com aspectos de ordem cultural histórica e filosófica. Nesse sentido, o romance de Eco faz uma espécie de prodígio. Em meio a uma busca frenética de um misterioso segundo livro da Poética, de Aristóteles, supostamente sobre a comédia e o riso, levanta uma discussão séria sobre um fenômeno cultural, cujos estudos remontam aos antigos gregos. Embora a trama

37 Hobbbes, Human nature: de corpore politico. London: Thoemmes Press, 1970, IX, 13 (apud MENEZES, 1974, p. 7). Nesse caso, parece que o riso tem lugar quando, algo que antes era respeitado e considerado, de repente, aparece como medíocre ou vil. 
transcorra num contexto policialesco, ${ }^{38}$ pois insere-se no grande esforço para desvendar o mistério de uma sucessão de mortes, leva-nos pensar que a tarefa de quem ama os homens é a de fazer com que eles riam, e riam de verdade. Nas entrelinhas, deixa imerso o pensamento de que a única verdade é aquela que nos leva a aprender a nos libertar da paixão insana pela verdade.

Desse modo, embora de forma diferente, Eco se insere entre os estudiosos que, especialmente a partir dos anos 70, vêm considerando o riso como campo privilegiado do saber. Daí a razão da organização de congressos internacionais, do surgimento de grupos de estudo congregando especialistas de distintos campos do saber, inclusive historiadores. Isso tudo é sinal de que tais pensadores se renderam ao poder de sedução do riso, levando-o à sério. Na França, por exemplo, em 1987, foi criada a CORHUM (Association pour le développement des recherches sur le Comique, le Rire et l'Humour), encarregada de pesquisas sobre o cômico, o riso e o humor, que organiza regularmente jornadas de estudo e colóquios sobre o assunto ${ }^{39} \mathrm{e}$ publica a revista semestral Humoresques. Nos Estados Unidos há uma revista interdisciplinar, International Journal of Humor Research, e em outros países há publicações similares. Reafirmando que o riso é "próprio do homem”, como postulou Aristóteles há mais de dois milênios, tenta-se mostrar, ainda, que os homens nem sempre riem das mesmas coisas e, tampouco, por razões idênticas.

O próprio Le Goff confessa que o romance de Eco teve influência nas suas pesquisas sobre o riso: "O nome da rosa teve seu papel na orientação de minha pesquisa, conforme eu notava que meu amigo Umberto Eco não estava menos convencido da importância do riso na sociedade e na cultura medievais” (LE GOFF, 1989, p. 71). Daí as pesquisas do historiador francês deixarem explicito o pressuposto de que o riso é um fenômeno cultural e social,

38 É bom lembrar que há um pluralismo de ideias a nortear o romance. Além da intriga policialesca, há a fascinação do mundo medieval através de diversas formas, a técnica literária mesclada de significados modernos explicativos, etc. Vê-se, por exemplo, no início do enredo, referências aos "preparativos" para uma reunião que aconteceria naquele mosteiro, congregando a corrente dos franciscanos chamada de fraticelli ou espirituais (daí as citações de João de Jandun, Marsílio de Pádua, Guilherme de Ockham), partidários da pobreza absoluta, e que apoiavam Luis da Baviera contra o papa João XXII e os dominicanos, em geral, defensores do Papa. Os beneditinos tendiam a uma posição conciliadora, mas em diversas passagens endossam as tendências franciscanas. Adson de Melk representa muito bem esta última tendência.

39 Desde 1988 a entidade tem promovido colóquio internacionais. Em m julho de 2000, por exemplo, ocorreu em Basençon, tendo como tema Dois mil anos de riso: permanência e modernidade. O útimo, aconteceu em julho de 2007, tendo como tema Faire rire : mode d'emploi. Analyse des procédés de la production d'humour. 
podendo ser classificado a partir de dois aspectos: o primeiro seria pelas atitudes em relação a ele; o segundo seria pelas manifestações expressas por outras pessoas. Desse modo, estudar o riso é deparar-se, com a história das atitudes e dos valores mentais, assim como das representações literárias e artísticas. O grande desafio de quem trabalha com o riso é interpretar a complexidade dos domínios que o mesmo envolve e a estética que cerca sua representação. Ao comentar que o riso é algo ligado ao corpo, observa sua manifestação através de três formas: o riso cômico, o espirituoso e o bem-humorado.

Umberto Eco procura abordar o riso a partir da vertente aristotélica e da leitura que algumas tendências do cristianismo começaram a fazer, dando matizes religiosos próprios da cultura ocidental. Porém, aquilo que Aristóteles definiu como "próprio do homem" pode assumir contornos culturais e, nesse sentido, está sujeito a interditos.

Pode-se perguntar, ainda hoje, sem qualquer resíduo de arcaísmo se é ou não permitido rir em determinadas circunstâncias. Ao se contemplar um cadáver, por exemplo, sua imagem pode suscitar riso, tanto aquele que diz respeito ao escárnio, como o que diz respeito ao cômico. Explicitando mais o exemplo, poder-se-ia dizer que, na contemplação do morto, num clima de seriedade, algo de cômico pode ser observado. É, provavelmente, o momento mais propício para se escarnecer do desafeto, pois nos permite contemplá-lo morto, inerte, sem o poder que ostentava, despido da fala autoritária que metia medo a muitos. Entretanto, pergunta-se: é o riso permitido naquele momento social em que tudo se volta para um sentimento de consternação? Daí o interdito. $\mathrm{O}$ ambiente silencioso não permite a eclosão da gargalhada e, desse modo, reprime-se o riso zombeteiro. E, o mesmo acontece em outras circunstâncias, como no ambiente religioso, por exemplo.

Ratifica-se, portanto, a ideia de que o riso é um fenômeno social e cultural. Em relação ao primeiro aspecto, não se deve esquecer a expressão de Bergson: "Não desfrutaríamos o cômico se nos sentíssemos isolados. O riso parece precisar de eco. O nosso riso é sempre o riso de um grupo" (BERGSON, 1987, p. 13). Em relação ao segundo, confirma-se que o riso traduz valores, revela padrões de comportamento, expressa convenções sociais aceitas pelo grupo ou estabelece o interdito de ações socialmente desaprovadas. Desse modo, resta-nos concluir, citando a máxima do historiador francês: "Diga-me se você ri, como ri, por que ri, de quem e do que ri, ao lado de quem e contra quem e eu te direi quem você é” (LE GOFF, 2000, p. 65). 


\section{REFERÊNCIAS}

ALBERTI, V. O riso e o risível na história do pensamento. Rio de Janeiro: Jorge Zahar; FGV, 1999.

APULEIO, L. O asno de ouro. Tradução de Ruth Guimarães. Rio de Janeiro: Ediouro, 1960.

BAKHTIN, M. M. A cultura popular na Idade Média e no Renascimento: o contexto de François Rabelais. São Paulo: Hucitec; Brasília: Ed. da UnB, 1993.

BERGSON, H. O riso: ensaio sobre a significação do cômico. Rio de Janeiro: Guanabara, 1987.

BAKHTIN, M. A cultura popular na Idade Média e no Renascimento: o contexto de François Rabelais. Tradução de Yara Frateschi Vieira. São Paulo: Hucitec, Brasília: Ed. da UnB, 1993.

CHELINI, J. Histoire religieuse de l'Occident médiéval. Paris: Armand Colin, 1968.

CLEMENT, A. Le pedagogue. Tradução de Marguerite Harl. Paris: Du Cerf, 1960. Livre II, cap. V, p. 99-105. (Sources chrétiennes, 70).

CURTIUS, E. R. Literatura européia e Idade Média Latina. Rio de Janeiro: Instituto Nacional do Livro, 1957.

DEMPF, A. Ética de la Edad Media. Madrid: Gredos, 1958.

DUVIGNAUD, J. Le propre de l'homme: histoire du rire e de la dérision. Paris: Hachette, 1985.

ECO, U. Pós-escrito ao Nome da rosa. Tradução de Letizia Zini Antunes e Álvaro Lorencine. Revisão Cléa Márcia Andrade Soares e Edílson Chaves Cantalice Uranga. 4. ed. Rio de Janeiro: Nova Fronteira, 1985. p. 7-10.

O nome da rosa. Tradução de Aurora Fornoni Bernardini e Homero Freitas de Andrade. São Paulo: Circulo do Livro, 1989. p. 94-103. 2002, p. 11.

Entrevista jornal mexicano. La Jornada Semanal, México, 2 e 9 de enero de

ENOUT, J. E. (Ed.). Benedicti Regula monachorum. Tradução de João Evangelista Enout. Rio de Janeiro: Lumen Christi, 1990. 217 p. Título original: A Regra de São Bento. Latim-português. 
DUVIGNAU, J. Le propre de l'homme: histoire du rire e de la dérision. Paris: Hachette, 1985. p. 20-22.

HERWEGEN, I. Sentido e espírito da regra de São Bento. Tradução Monges do Mosteiro de São Bento. Rio de Janeiro: Lumen Christi, 1953.

JEKOVIC , J. Duas ou três coisas que eu sei do humor. Revista de Cultura Vozes, Petrópolis, ano 64, vol. LXIV, n. 3, 1970.

KASSEL, R. Aristotelis de arte poetica líber. New York: Oxford University Press, 1965.

KOLVE, V. A. The play called Corpus Christi. Stanford: Stanford University Press, 1966.

LE GOFF, J. Rire au Moyen Age. Cahiers du Centre de Recherches Historique, Paris, n. 3, p. $1-14,1989$.

Jésus a-t-il ri? L'Histoire, n. 158, p. 72-74, 1992.

O riso na Idade Média. In: BREMMER, J.; ROODENBURG, H. (Org.). Uma historia cultural do humor. Rio de Janeiro: Record, 2000. p. 63-82.

Nicolas Truong: uma história do corpo na Idade Média. Rio de Janeiro: Civilização Brasileira, 2006.

MACEDO, J. R. de. Riso ritual, cultos pagãos e moral cristã na Alta Idade Média. Boletim do CPA, Campinas, n. 4, p. 87-110, 1997.

Riso, cultura e sociedade na Idade Média. Porto Alegre: Ed. da UFRGS; São Paulo: Ed. da Unesp, 2000.

MAGNO, B. As regras monásticas. Tradução de Hildegardis Pasch e Helena Nagem Assad. Petrópolis: Vozes, 1983.

MENEZES, E. D. B. de. O riso, o cômico e o lúdico. Revista de Cultura Vozes, Petrópolis, v. 68, n. 1, p. 7-21, 1974.

OTTO, R. O sagrado: um estudo do elemento não racional na idéia do divino e sua relação com o racional. Tradução de Prócoro Velasquez Filho. São Bernardo do Campo: Metodista, 1985.

PORFÍRIO. Isagoge. São Paulo: Maltese, 1965. 
RABELAIS, F. Gargantua. São Paulo: Hucitec, 1986.

SAINT AUGUSTIN. De catechizandis rudibus. In: Oeuvres de Saint Augustin. Paris: Desclée de Brouwer, 1949. Tome 11, p. 54-80.

SAMÓSATA, L. de. Lúcio ou o asno. Tradução de Custódio Magueijo. Lisboa: Inquérito, 1973.

.Uma história verídica. Tradução de Custódio Magueijo. Lisboa: Inquérito, 1989.

Diálogos dos mortos. Tradução de Maria Celeste Consolin Dezotti. São Paulo: Hucitec, 1996.

. Hermótimo ou as escolas de filosofia. Tradução de Custódio Magueijo. Lisboa: Inquérito, 1996.

SCHMITT, J-C. Problemas do mito no Ocidente Medieval. Tradução de Denise Maria Cogo. In: DONALD, S.; GOETTEMS, M. B. (Org.). Mito: ontem e hoje. Porto Alegre: EDURGS, 1990.

SKINNER, Q. A arma do riso. Folha de São Paulo, São Paulo, Suplemento Mais!, 04 de agosto de 2002.

VERENA, A. O riso e o risível na história do pensamento. Rio de Janeiro: Jorge Zahar; FGV, 1999.

VOELTZEL, R. Le rire du Seigneur: enquêtes et remarques sur la signification théologique et practique de l'ironie biblique. Strasbourg: Oberlin, 1955.

VOGUE, A. La Règle de saint Benoît. Paris: Cerf, 1972.

YEBRA, V. G. Poetica de Aristotoles. Edición trilingue. Madrid: Gredos, 1974.

Recebido: $15 / 12 / 2008$

Received: $12 / 15 / 2008$

Aprovado: 22/01/2009

Approved: 01/22/2009

Revisado: 02/10/2009

Reviewed: 10/02/2009 